\title{
Influence of shape modification and stirrups on the axial capacity of concrete columns
}

\author{
Ida Bagus Rai Widiarsa ${ }^{1, *}$ and Ida Bagus Dharma Giri ${ }^{1}$ \\ ${ }^{1}$ Civil Engineering Department, University of Udayana, Bali - Indonesia
}

\begin{abstract}
Columns as an important element of building structures support loads that work on slabs and beams and deliver the loads to the foundation. Concrete columns can experience strength degradation due to several reasons such as having less concrete strength than designed due to construction error or environmental damage. To restore the strength capacity of the columns, rehabilitation or retrofitting methods with steel plates or Fibre-Reinforced-Polymer (FRP) sheets are generally applied. This method is effective if the shape of the column is rounded. However, the shape of the column in the field is commonly rectangular or squared. Moreover, retrofitting using FRP is very expensive. Based on this background, this study examined the effect of shape modification and stirrup on the axial capacity of concrete columns. A total of 12 specimens of concrete columns were cast and tested. The specimens were grouped into 4, with variations in shape and stirrup spacing. The experimental results showed that the shape modification increased the axial capacity of the concrete column. Shape modification and addition of stirrups at the same time increased the axial capacity of the concrete columns more significantly. Furthermore, the shape modification and addition of stirrups improved the performance of the columns.
\end{abstract}

\section{Introduction}

A building structure generally consists of many structural elements, in which each element has different but interconnected functions. Columns are very important structural elements in ensuring that the structure does not collapse. The main function of columns is to support forces acting on plates and beams, and forward them to the foundation.

Columns are elements of the frame structure predominantly receiving axial forces. Generally, the failure or collapse of the compressive structural element does not start with a clear warning, but occurs suddenly. Therefore, column structures should be carefully calculated by providing higher reserve strength [1].

In the element of reinforced concrete structures, especially the axial and bending structural elements, their ductility is strongly influenced by the confinement by the stirrups. Confinement by stirrups on the axial structural elements will only work after a considerable crack and compressive force at the time approaching the axial force without confinement [2].

* Corresponding author: r widiarsa@yahoo.com 
A number of researches on the stirrups were reported [3] on short columns of rectangular sectioned reinforced concrete. The study concluded that confinement can increase the ductility and strength of the column. The smaller the spacing of the stirrups, the larger the ability of the column in supporting the load. The same results were also obtained from a study conducted by Binawati [4] and Purnawan [5].

Sometimes in the field, reinforced concrete columns that have been designed according to structural requirements in fact experienced a condition where the load capacity is less than the design load after the construction process. This may be due to damage caused by poor construction processes. Therefore, it is required to restore the strength of the column back to the designed strength. One method, for example, is by structural retrofitting or rehabilitation. A common rehabilitation method performed on reinforced concrete columns is by wrapping columns with FRP (FRP confinement). This method works effectively if the column shape is rounded or circular. But in reality, reinforced concrete columns generally are square or rectangular in section.

Based on this background, the effect of confinement with stirrups to the axial capacity of concrete columns were investigated. However, unlike in the field where reinforcement has been cast in the concrete since the beginning of the column construction, in this study the addition of stirrups bars is applied outside the existing concrete column at the same time with changes to the dimension and shape of the columns (shape modification). The initial tested specimens were square rectangular specimens, after which the specimens were modified into a circular shape. The axial capacity of unmodified concrete columns was compared with that of the modified concrete columns, either with or without stirrups.

\section{Experimental program}

The experimental program of this study was conducted at the Structural and Materials Laboratory of Civil Engineering Department at the University of Udayana, Bali.

\subsection{Specimens}

Data of the experimental study was collected from a series of compression testing on a total of twelve concrete column specimens. The column specimens were grouped into 4 , with a configuration as shown in Table 1. Each group consisted of 3 specimens. The initial dimension of the column specimens was $80 \times 80 \times 300 \mathrm{~mm}$ which had a square section. Three column specimens were left as square columns (K Columns). The remaining column specimens were then put centred into a cylinder mould with a diameter of $150 \mathrm{~mm}$ and a height of $300 \mathrm{~mm}$. Then they were cast again by pouring concrete surrounding the square columns, changing the columns' shape into circular columns. This process is called shape modification. For Groups S1 and S2, stirrups were also applied simultaneously with the shape modification. The concrete column specimens with their configuration are shown in Figure 1.

\subsection{Material properties}

All column specimens tested in this study were constructed with concrete casts in the laboratory. The compressive strengths of the specimens were determined by conducting compression tests on $150 \mathrm{~mm}$ diameter concrete cylinders. The tests were done two times, first for the concrete of the square column specimens and the second for the concrete that surrounded the square column specimens. The average 28-day compressive strength of the concrete for the first tests was $39.24 \mathrm{MPa}$, whereas for the second tests this was $38.44 \mathrm{MPa}$. 
No longitudinal reinforcement was applied in the column specimens. There were only stirrups applied with a spacing of $65 \mathrm{~mm}$ for Group S1 and 32,5 mm for Group S2. The stirrups used were 6-mm steel rebar.

Table 1. Configuration of column specimens.

\begin{tabular}{|c|c|c|c|}
\hline Specimen group & Reinforcement & $\begin{array}{c}\text { Initial dimension } \\
(\mathbf{m m})\end{array}$ & $\begin{array}{c}\text { Tested dimension } \\
(\mathbf{m m})\end{array}$ \\
\hline $\mathrm{K}$ & No stirrup & $80 \times 80 \times 300$ & $80 \times 80 \times 300$ \\
\hline $\mathrm{S} 0$ & No stirrup & $80 \times 80 \times 300$ & $\begin{array}{c}\text { Diameter } 150 \mathrm{~mm}, \\
\text { height } 300 \mathrm{~mm}\end{array}$ \\
\hline $\mathrm{S} 1$ & $\begin{array}{c}\text { With stirrup spacing at } \\
\mathrm{s}=65 \mathrm{~mm}\end{array}$ & $80 \times 80 \times 300$ & $\begin{array}{c}\text { Diameter } 150 \mathrm{~mm}, \\
\text { height } 300 \mathrm{~mm}\end{array}$ \\
\hline $\mathrm{S} 2$ & $\begin{array}{c}\text { With stirrup spacing at } \\
\mathrm{s}=32.5 \mathrm{~mm}\end{array}$ & $80 \times 80 \times 300$ & $\begin{array}{c}\text { Diameter } 150 \mathrm{~mm}, \\
\text { height } 300 \mathrm{~mm}\end{array}$ \\
\hline
\end{tabular}

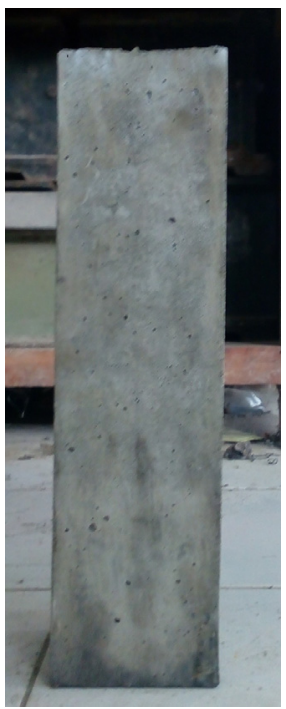

(a)

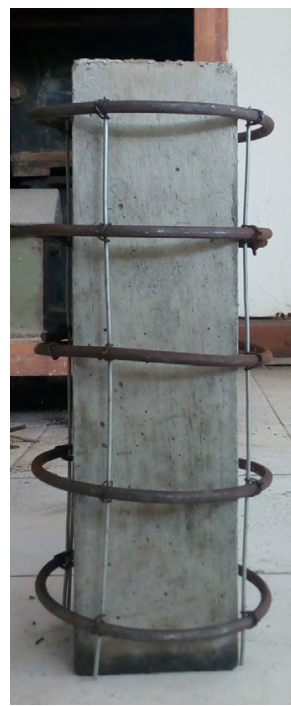

(b)

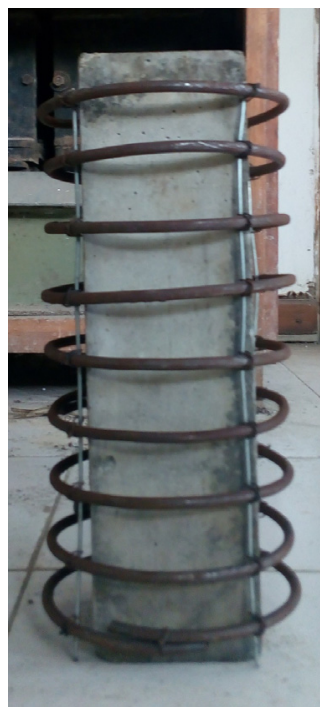

(c)

Fig. 1. Concrete columns configuration: (a) Without stirrup, (b) With stirrups $\mathrm{s}=65 \mathrm{~mm}$, (c) With stirrups $\mathrm{s}=32.5 \mathrm{~mm}$.

\subsection{Test setup}

A $2000 \mathrm{kN}$ compression testing machine was used to conduct the compressive tests on all of the column specimens. The data of load and displacement were recorded simultaneously from the beginning of the tests until the failure of the column specimens was reached.

\section{Results and discussion}




\subsection{Failure of columns specimens}

In compression testing, besides recording the load and displacement relationship of the column specimens, the modes of failure of the column specimens were also observed. The failure modes of the column specimens during the loading tests are shown in Fig. $2-5$.

The failure of the K Columns started with hair cracking. As the load increased and the column specimen shortened, the crack widened and extended. The column specimens failed at an average compressive strength of $25.52 \mathrm{MPa}$. The failure of the K Columns are shown in Fig. 2.

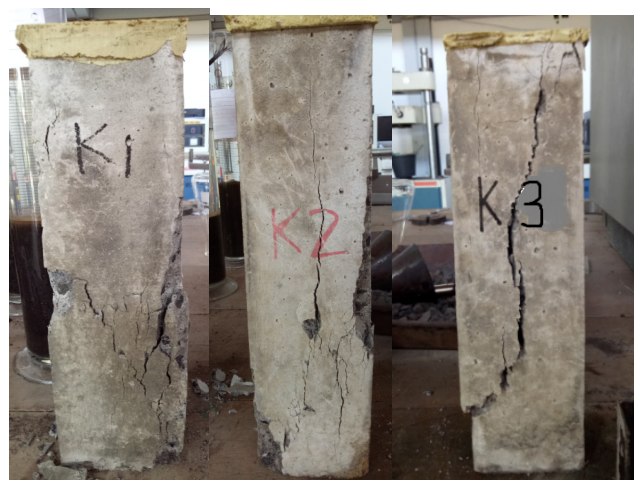

Fig. 2. Failure mode of the K Columns.

In the columns with shape modification, i.e. the S0 Columns, all specimens experiencing similar mode with Columns $\mathrm{K}$. The failure occurred at an average compressive strength of $28,47 \mathrm{MPa}$. A brittle failure was observed and the failure was shown in Fig. 3.

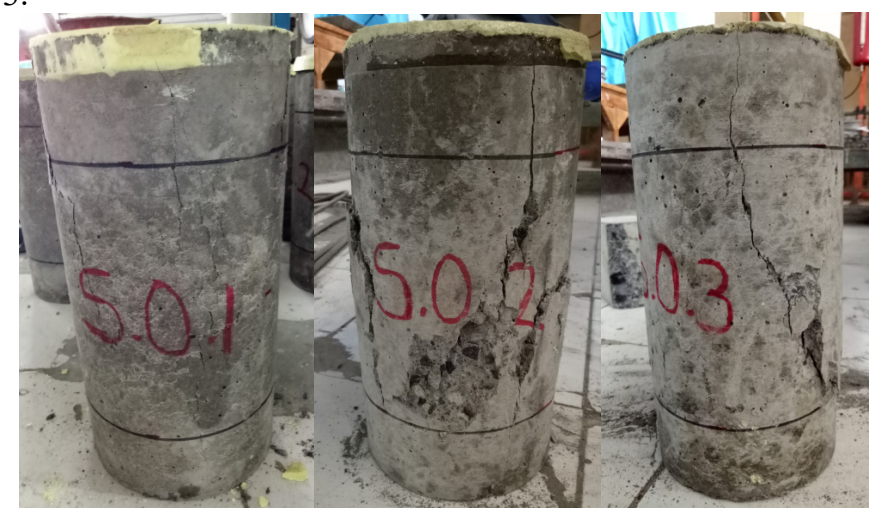

Fig. 3. Failure mode of the S0 Columns.

In columns with shape modifications and stirrups (the S1 and S2 Columns), the failure started with a hair crack. Then the crack widened and extended as the load increased. At the same time the lateral dimension changed and the column specimens shortened which caused the concrete cover to peel off (spalling). The core of the column specimens was not split as shown in Fig. 4 and 5. 


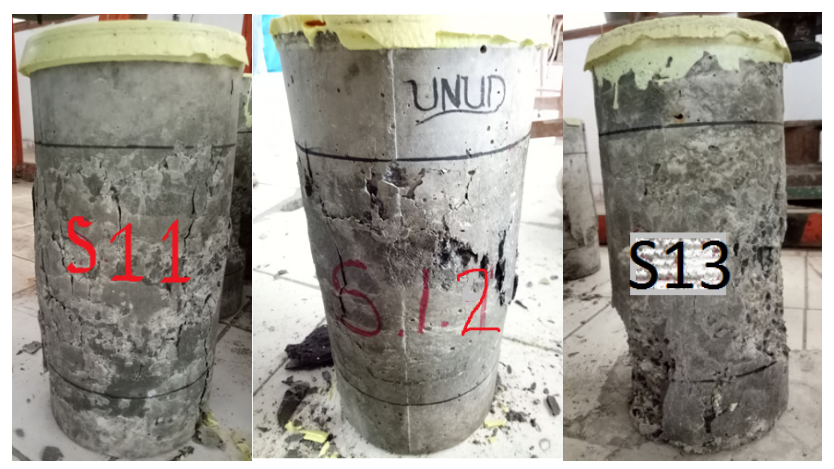

Fig. 4. Failure mode of the S1 Columns.

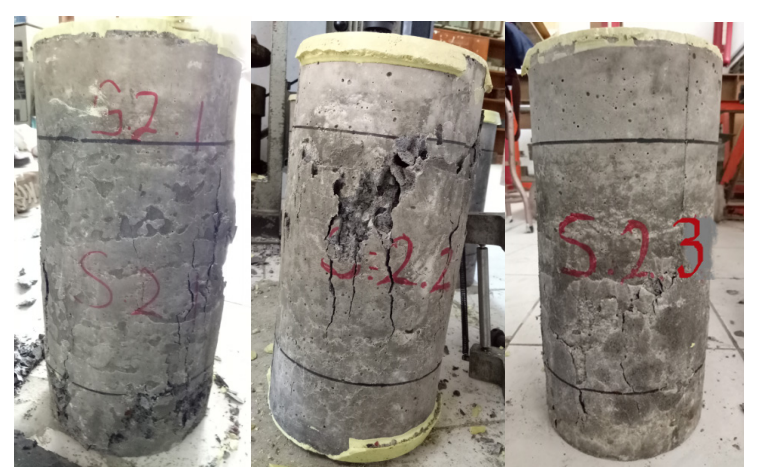

Fig. 5. Failure mode of the S2 Columns.

\subsection{Load-displacement relationship}

During the compression tests, a dial gauge was also installed for measuring the shortening of the column specimens. The columns shortening, i.e. displacement, was then plotted in the diagram for each corresponding load. The load - displacement diagrams for the Groups $\mathrm{K}, \mathrm{S} 0, \mathrm{~S} 1$ and S2 are shown respectively in Fig. $6-9$.

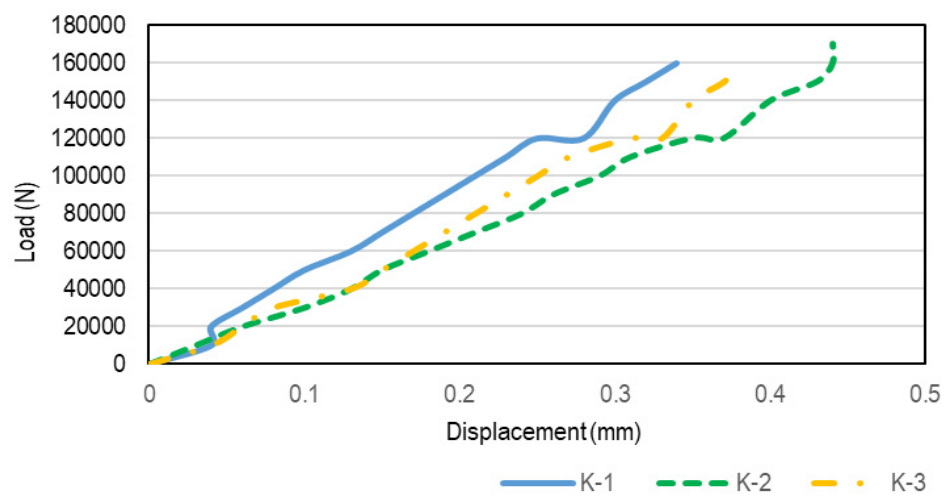

Fig. 6. Load-displacement diagram of the K Columns. 
It can be seen in Fig. 6 that in Group K the load increased proportionally with the shortening of the columns until the column failed. Different conditions were observed in the S0, S1 and S2 Columns where the increasing load was not proportional with the displacement of the columns.

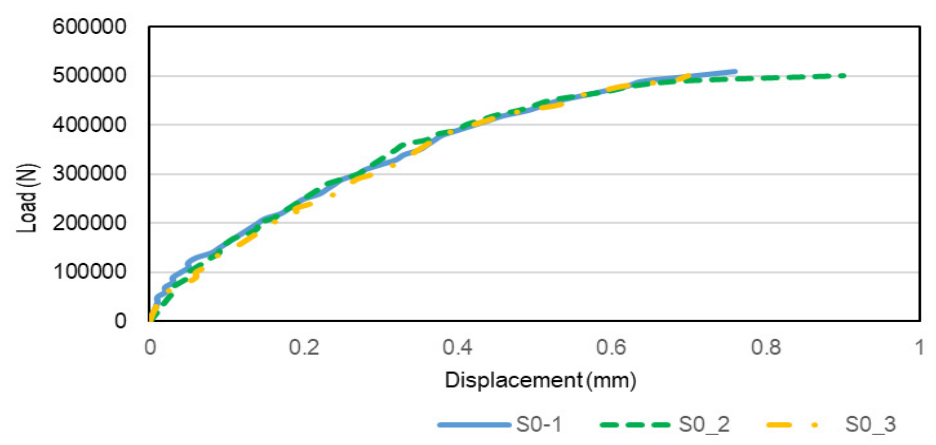

Fig. 7. Load-displacement diagram of the S0 Columns.

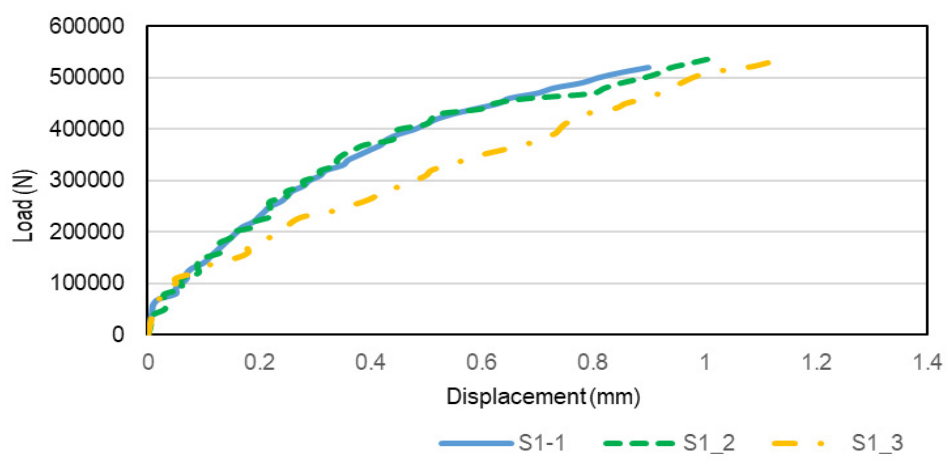

Fig. 8. Load-displacement diagram of the S1 Columns.

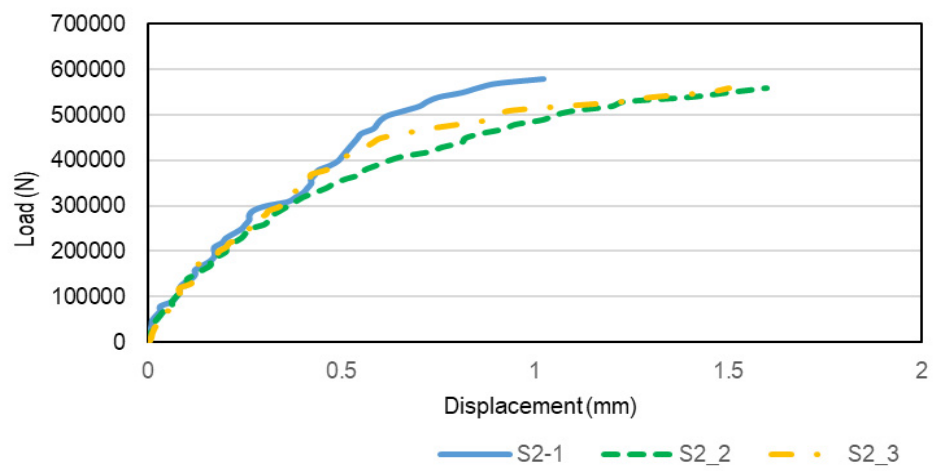

Fig. 9. Load-displacement diagram of the S2 Columns.

The effect of the shape modification and addition of stirrups to the axial capacity of the columns can be seen from Fig. 10. The K Columns failed when the average load reached $163 \mathrm{kN}$ with an average displacement of $0.39 \mathrm{~mm}$. Meanwhile the S0, S1 and S2 Columns experienced failure when the average load respectively reached $503 \mathrm{kN}, 530 \mathrm{kN}$ and 566 
$\mathrm{kN}$ and the average displacement respectively reached $0.79 \mathrm{~mm}, 1.01 \mathrm{~mm}$ and $1.37 \mathrm{~mm}$. Shape modification from squares (Group K) into a circular shape (Group S0) increased the axial capacity of the columns by $209 \%$. Meanwhile, the effect of adding stirrups and shape modification increased the axial column capacity by $225 \%$ (Group K to Group S1) and $247 \%$ (Group K to Group S2).

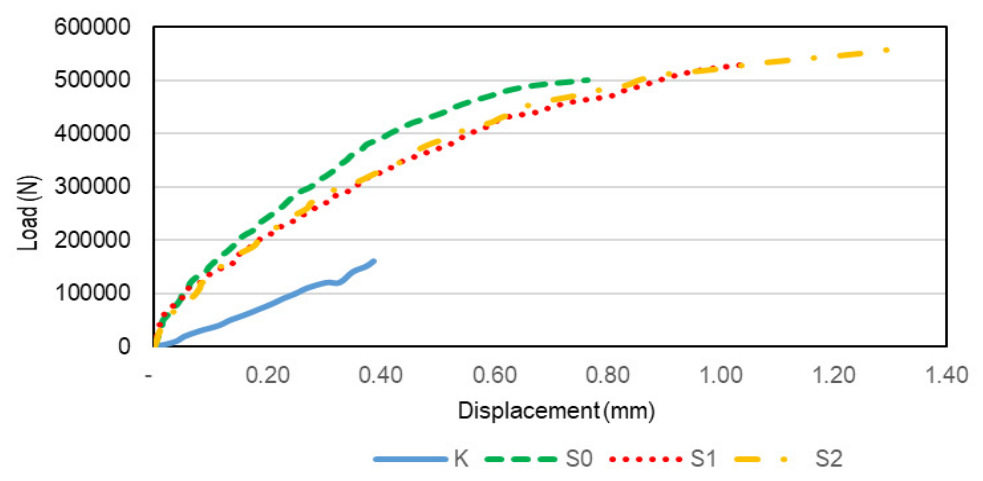

Fig. 10. Load-displacement diagram of the Groups K, S0, S1 and S2.

From Fig. 10, it can also be seen that the shape modification and addition of stirrups improved the performance of the columns. In this case, the columns' performance can be assumed to be the area under the load - displacement diagram of the columns. The performance of the column relates to the column ductility: the greater the performance of the columns, the greater the ductility. In the columns with stirrups, minimizing the spacing of the stirrups (from Group S1 to Group S2) improved the performance of the columns.

\section{Conclusions and recommendations}

\subsection{Conclusions}

Based on the analysis of the experimental results, some conclusions can be drawn as follows:

- The addition of stirrups increased the axial capacity of the concrete columns.

- Change in the spacing of the stirrups affected the axial capacity of the concrete columns.

- Shape modification, which is the change of dimension and section shape, increased the axial capacity of the concrete columns.

- Shape modification and addition of stirrups improved the performance of the columns.

\subsection{Recommendations}

From the results of this study, further research can be recommended using different configurations applied simultaneously with shape modification.

\section{References}

1. Tavio, R. Purwono, dan A. Rosyidah. "Peningkatan Daya Dukung dan Daktilitas Balok Beton Bertulang dengan Menggunakan Perkuatan CFRP (Carbon Fiber 
Reinforced Polymer), Jurnal Dinamika Teknik Sipil ITS. 9, Nomor 1, Januari, pp. 9-18. (2009).

2. R. Park and T. Paulay, Reinforced Concrete Structures. USA: John Wiley and Sons Inc. (1975).

3. S. A. Sheikh and S. M. Uzumeri, "Analytical Model for Concrete Confinement in Tied Columns", ASCE Journal of the Structural Division. 108 (12), p. 2703-2722. (1982).

4. V. Binawaty, "Pengaruh Rasio Volumetrik Sengkang dan Penutup Beton terhadap Daya Dukung Aksial Tekan dan Daktilitas Kolom Bulat Beton Bertulang”. Tugas Akhir (Tidak Ditebitkan). Program Studi Teknik Sipil Fakultas Teknik Universitas Udayana. Denpasar. (2004).

5. K. Purnawan, Pengaruh Rasio Volumetrik terhadap Kapasitas Aksial Tekan dan Daktilitas Kolom Bulat Beton Bertulang Penampang Pipih. Tugas Akhir (Tidak Diterbitkan). Program Studi Teknik Sipil Fakultas Teknik Universitas Udayana. Denpasar. (2011) 